\title{
AN EFFECTIVE CHILD-LABOR LAW
}

\section{A Program for the Current Decade.}

The subject assigned for this paper was "An Ideal Child-Labor Law." But it has been pointed out with great force by Dr. Emil G. C. Hirsch, that the word child-labor consists of parts which should not be joined together; that work of the character suitably designated as labor is foreign to the whole nature of the child and is to be regarded as in itself an evil. Even greater then is the contradiction within the term "An Ideal Child-Labor Law," unless indeed it were used to describe a sweeping prohibition of all labor for all children. Since, however, such a prohibition is not at present within the bounds of practical discussion, I have ventured to state the problem in the terms "An Effective Child-Labor Law" and have striven to indicate both the best that has been accomplished in the various states, and the steps which it now seems reasonable to look forward to and to work for during the decade 1900-19io.

First anong all the aims to be striven for is uniformity among the states on the basis of the best that has already been accomplished in the most enlightened states. For lack of uniformity progress has been hindered during the past winter in many states, notably in the case of the glass industry which has represented successfully to legislators at Harrisburg, Pa., at Springfield, Ill., and at Trenton, $\mathrm{N}$. J., that proposed restrictions upon the night work of young boys, or upon the employment of illiterate children, would place the manufacturers in any one of these states at a disadvantage in competition with manufacturers in any other; the result being that nothing has yet been accomplished in any of the three states for the needed protection of the children in these essential respects. A concerted effort in all three states for a uniform measure would have met successfully the objections urged in all.

It is to be borne in mind in all discussions of child-labor laws that they are drawn in the interest of the weakest elements in the community. It is the recently immigrated family in the North and the "poor whites" in the South whose children are found at work." It is, therefore, probable that a rigid exclusion of all work of chil-

\footnotetext{
1 In many years of intimate acquaintance with the sweating system, for instance, $I$ have never seen a native child of native parents in a sweat-shop.
} 
dren under the age of sixteen years, while inflicting hardship upon some families already here and involving, perhaps, some need of assistance for them on the part of the community, would act as a check upon the immigration of the least desirable foreigners,who come in the hope of exploiting their young children,-and would somewhat deter the migration of the mountain whites in the South to the mill towns. In Massachusetts, at the past two sessions of the legislature, a bill has been introduced which would raise the minimum age for employment to sixteen years; and there is no doubt that this bill will be introduced at every session until it finally becomes the law of the most enlightened of the great manufacturing states of the Union. Meanwhile, however, in the interest of the effort for uniformity, it has seemed more practicable to adopt as the minimum age for beginning work, the fourteenth birthday; while endeavoring to bring to this minimum all the children now engaged in street occupations hitherto exempt from restrictions in nearly all the states; and endeavoring, also, to bring to this minimum the statutes of those states which as yet prescribe either no minimum age, or a minimum set at ten years (as in the new laws of South Carolina and Alabama), or twelve years (as in the laws of North Carolina and California), or thirteen years (as in the law of Pennsylvania). No one acquainted with the diminutive stature of city children of the working class at the age of fourteen years, can regard the adoption of this standard minimum age for beginning work as final. It is merely the best attainable for the prsent and the immediate future in the evolution of child-labor legislation.

In the century since the movement for child-labor legislation began with Sir Robert Peel's act of 1802 , effort has been devoted chiefly to placing about the labor of children restrictions based upon age or school requirements and these have been found unsatisfactory by reason of the defective registration of births and the readiness of parents to perjure themselves. It is the tendency of the present to consider the physical fitness of the child itself; and to establish an objective test of fitness for the occupation which the child enters. This has taken primarily the negative form of prohibiting for all children certain specified industries in Massachusetts and New York; and of prohibiting in general, in Ohio, "any occupations dangerous to life and limb or whereby its health is likely to be injured or its morals may be depraved." In Illinois, the idea 
is tentatively expressed in the authority given the factory inspector to require a certificate of physical fitness for any child who may seem physically unfit for the work at which it is engaged. A law enacted by the legislature of New York during the past winter provides that a child must be "of normal development and is in sound health" before receiving the certificate of the local Board of Health enabling it to begin work.

Effective legislation dealing with child-labor involves many differing elements including the child, the parent, the employer, the officials charged with the duty of enforcing the statutes, and finally the community which enacts laws, provides schools for the children when they are prohibited from working, supports and authorizes officers for the enforcement of the laws, prescribes penalties for their violation, assists dependent families in which the children are below the legal age for work. In the long run, the effectiveness of the law depends upon the conscience of the community as a whole far more than upon the parent and the employer acting together.

With the foregoing reservations and qualifications duly emphasized, the following schedules are believed to outline the substance of the effective legislation which it seems reasonable to try to secure in the present and the immediate future. They deal only with provisions for the child as a child, taking for granted the provision for fire-escapes, safeguards for machines, toilet facilities and all those things which the child shares with the adult worker.

An effective child-labor law rests primarily upon certain definite prohibitions among which are the following:

\section{Labor is Prohibited}

(I) for all children under the age of fourteen years,

(2) for all children under sixteen years of age who do not measure sixty inches and weigh eighty pounds,

(3) for all children under sixteen years of age who cannot read fluently and write legibly simple sentences in the English language.

(4) for all children under the age of sixteen years, between the hours of $7 \mathrm{p}$. m. and $7 \mathrm{a} . \mathrm{m}$., or longer than eight hours in any twenty-four hours.

(5) for all children under the age of sixteen years in occupa- 
tions designated as dangerous by certain responsible officials.

Of the foregoing prohibitions Number $I$ is in force in a number of states so far as work in factories, stores, offices, laundries, etc., is concerned. In New York and Massachusetts recent statutes restrict, though they do not yet prohibit outright, work in the street occupations for children under the age of fourteen years. The movement in this direction gained marked headway during the past winter. Number 2 is not yet embraced in any statute, but is vigorously advocated by many physicians and others practically acquainted with working children. Number 3 has long been the law in New York State, and is of the highest value to the immigrant children so far as it is enforced. Number 4 is in force in Ohio. Number 5 is in force in Massachusetts.

\section{The Child.}

Effective legislation requires that before going to work the child satisfy a competent officer appointed for the purpose, that it

(I) is fourteen years of age, and

(2) is in good health, and

(3) measures at least sixty inches and weighs eighty pounds, and

(4) is able to read fluently and write legibly simple sentences in the English language, and

(5) has attended school a full school year during the twelve months next preceding going to work.

\section{The Parent.}

Effective child-labor legislation requires that the parent

(I) keep the child in school to the age of fourteen years, and

(2) take oath as to the exact age of the child before letting it begin to work, and

(3) substantiate the oath by producing a transcript of the official record of the birth of the child, or the record of its baptism, or some other religious record of the time of the birth of the child, and must

(4) produce the record.of the child's school attendance, signed by the principal of the school which the child last attended. 


\section{The Employer.}

Effective child-labor legislation requires that the employer before letting the child begin to work,

(I) obtain and place on file ready for official inspection papers showing

(a) the place and date of birth of the child substantiated by

(b) the oath of the parent corroborated by

(c) a transcript of the official register of births, or by a transcript of the record of baptism, or other religious record of the birth of the child, and by

(d) the school record signed by the principal of the school which the child last attended, and by

(e) the statement of the officer of the Board of Education designated for the purpose, that he has approved the papers and examined the child.

(2) After permitting the child to begin to work, the employer is required to produce the foregoing papers on demand of the school-attendance officer, the health officer and the factory inspectors.

(3) In case the child cease to work, the employer must restore to the child the papers enumerated above.

(4) During the time that the child is at work, the employer must provide suitable seats, and permit their -use so far as the nature of the work allows; and must

(5) post and keep posted in a conspicuous place, the hours for beginning work in the morning, and for stopping work in the middle of the day; the hours for resuming work and for stopping at the close of the day; and all work done at any time not specified in such posted notice constitutes a violation of the law. The total unmber of hours must not exceed eight in any one day or fortyeight in one week.

\section{The Officials.}

Effective legislation for the protection of children requires that the officials entrusted with the duty of enforcing it

(I) give their whole time, not less than eight hours of every [442] 
working day, to the performance of their duties, making night inspections whenever this may be necessary to insure that children are not working during the prohibited hours ; and

(2) treat all employers alike, irrespective of political considerations, of race, religion or power in a community;

(3) prosecute all violations of the law;

(4) keep records complete and intelligible enough to facilitate the enactment of legislation suitable to the changing conditions of industry.

\section{The School.}

The best child-labor law is a compulsory education law covering forty weeks of the year and requiring the consecutive attendance of all the children to the age of fourteen years. It is never certain that children are not at work, if they are out of school. In order to keep the children, however, it is not enough to compel attendance,the schools must be modified and adapted to the needs of the recent immigrants in the North and of the poor whites in the South, affording instruction which appeals to the parents as worth having, in lieu of the wages which the children are forbidden to earn, and appeals to the children as interesting and attractive. These requirements are so insufficiently met in the great manufacturing centres of the North, that truancy is in several of them, at present, an insoluble problem. No system of child-labor legislation can be regarded as effective which does not face and deal with these facts.

The evolution of the vacation school and camp promises strong reinforcement of the child-labor laws; which are now seriously weakened by the fact that the long vacation leaves idle upon the streets children whom employers covet by reason of the low price of their labor, while parents, greedy for the children's earnings and anxious lest the children suffer from the life of the streets, eagerly seek work for them. Nothing could be worse for the physique of the school child than being compelled to work during the summer; and the development of the vacation school and vacation camp alone seems to promise a satisfactory solution of the problem of the vacation of the city child of the working class. 


\section{The Community.}

Effective child-labor legislation imposes upon the community many duties, among which are

(I) maintaining officials-men and women-school-atendance officers, health officers, and factory inspectors, all of whom need

(a) salary and traveling expenses,

(b) access at all reasonable times to the places where children are employed,

(c) power to prosecute all violations of the statutes affecting working children.

(d) tenure of office so effectively assured that they need not fear removal from office in consequence of prosecuting powerful offenders;

(2) maintaining schools in which to educate the children who are prohibited from working;

(3) maintaining vital statistics, especially birth records, such that the real age of native children may be readily ascertained;

(4) maintaining provision for the adequate relief of dependent families in which the children are not yet of legal age for beginning work.

More important, however, than the enactment of the foregoing provisions is the maintenance in the community of a persistent, lively interest in the enforcement of the child-labor statutes. Without such interest, judges do not enforce penalties against offending parents and employers; inspectors become discouraged and demoralized; or faithful officers are removed because they have no organized backing while some group of powerful industries clamors that the law is injuring its interest. Well-meaning employers grow careless, infractions become the rule, and workingmen form the habit of thinking that laws inimical to their interest are enforced, while those framed in their interest are broken with impunity.

Upon parents there presses incessant poverty, urging them to seek opportunities for wage-earning even for the youngest children; and upon the employers presses incessant competition, urging them to reduce the pay-roll by all means fair and foul. No law enforces itself; and no officials can enforce a law which depends upon them 
alone. It is only when they are consciously the agents of the will of the people that they can make the law really protect the children effectively.

\section{Florence Kelley.}

Secretary National Consumers' League, 